\title{
Pengaruh Metode Pembelajaran dan Kemampuan Berpikir Kritis Terhadap Hasil Belajar Sejarah Siswa
}

\author{
Oleh : Lukas Nana Rosana \\ Program Pascasarjana Universitas Negeri Jakarta \\ pps12lukas@yahoo.com
}

\begin{abstract}
Abstrack
The objective of this research was to determine effect of learning method and critical thinking ability toward students' outcome of learning history at Bunda Hati Kudus Senior High School in Jakarta. This research uses experimental method with treatment of level $2 \times 2$. The target of sampling population is Bunda Hati Kudus Senior High School Jakarta. The eleventh graders of social one are as the treating sample and the eleventh graders of social two are as controlling popullation.

This research gives conclusion as follows: (1) students' outcome of learning history whom given model make a match of cooperative learning method are higher than students' outcome whom given convensional learning method; (2) there is an interactive effect between learning method and critical thinking ability toward learning history outcome; (3) students' outcome of learning history who have high critical thinking ability, were given model make a match of cooperative learning method higher than students who were given convensional learning method; (4) students' outcome of learning history who have low critical thinking ability, were given model make a match of cooperative learning method lower than students who have low critical thinking, were given conventional learning method.
\end{abstract}

Keywords : history learning outcome, learning methods, and critical thinking abilities

\begin{abstract}
Abstrak
Penelitian ini bertujuan untuk mengetahui pengaruh metode pembelajaran dan kemampuan berpikir kritis siswa terhadap hasil belajar sejarah siswa di SMA Bunda Hati Kudus. Penelitian ini menggunakan metode eksperimen dengan treatment by level $2 \times 2$. Polupasinya adalah SMA Bunda Hati Kudus Jakarta dengan sampel siswa kelas XI IPS 1 sebagai kelas eksperimen dan kelas XI IPS 2 sebagai kelas kontrol.

Kesimpulan dari penelitian ini adalah sebagai berikut: (1) hasil belajar sejarah antara siswa yang diberikan metode pembelajaran kooperatif model mencari pasangan lebih tinggi dari siswa yang diberikan metode pembelajaran konvensional; (2) terdapat pengaruh interaksi antara metode pembelajaran dan kemampuan berpikir kritis terhadap hasil belajar sejarah siswa; (3) hasil belajar sejarah siswa yang diberikan metode pembelajaran kooperatif model mencari pasangan dengan kemampuan berpikir kritis tinggi lebih tinggi dari siswa yang diberikan metode pembelajaran konvensional dengan kemampuan berpikir kritis tinggi; (4) hasil belajar sejarah siswa yang diberikan metode pembelajaran kooperatif model mencari pasangan dengan kemampuan berpikir kritis rendah lebih rendah dari siswa yang diberikan metode pembelajaran konvensional dengan kemampuan berpikir kritis rendah
\end{abstract}

Kata kunci : hasil belajar sejarah, metode pembelajaran, dan kemampuan berpikir kritis 


\section{Pendahuluan}

Hapsari (2011: 14) menyatakan bahwa pendidikan sejarah di sekolah menengah memiliki arti yang strategis untuk membentuk watak dan peradaban bangsa yang bermartabat, serta pembentukan manusia Indonesia yang memiliki rasa kebanggaan dan cinta tanah air, mampu meningkatkan kemampuan berpikir dan kemampuan menggunakan semua yang telah dipelajari dalam kehidupannya melalui pemaknaan peristiwa sejarah. Tujuan ini dapat dicapai melalui proses pembelajaran dengan menggunakan berbagai metode pembelajaran yang sesuai karakteristik siswa dan tantangan jaman.

Guru sebagai pengelola pembelajaran dapat melaksanakan proses pembelajaran dengan menerapkan pembelajaran kooperatif dan pembelajaran kritis. Pembelajaran ini menelaah keterkaitan kehidupan yang dialami seseorang, masyarakat dan bangsanya sehingga para siswa menjadi generasi muda yang memiliki kesadaran sejarah, mendapatkan inspirasi ataupun makna dari kisah-kisah kepahlawanan yang pada akhirnya mendorong terbentuknya pola berpikir kritis. Penggunaan metode pembelajaran kooperatif dalam mengembangkan kemampuan berpikir kristis siswa masih merupakan harapan yang belum sesuai kenyataan. Berdasarkan pengamatan peneliti, metode pembelajaran yang digunakan dari waktu ke waktu tidak mengalami perubahan yang berarti.

Kurangnya motivasi dan pemahaman guru dalam menggunakan berbagai metode pembelajaran berdampak pada proses pembelajaran. Siswa kurang tertantang oleh cara pembelajaran guru yang monoton. Mereka cenderung pasif dalam proses pembelajara karena pembelajaran hanya mengingat fakta-fakta sejarah tanpa adanya manfaat bagi siswa.

Pengembangan kurikulum berkaitan dengan tantangan era global, tuntutan kemampuan dalam berkolaborasi antarbangsa, dan kemampuan berpikir. Oleh karena itu metode pembelajaran kooperatif dapat digunakan sebagai solusi mengembangkan kemampuan sosial dan berpikir kritis siswa. Metode pembelajaran sejarah sebaiknya bersifat terbuka dan dialogis yang melibatkan siswa dalam kelompok-kelompok kecil dan diarahkan untuk mengembangkan kemampuan berpikirnya sehingga siswa berperan memecahkan permasalahan dan melahirkan banyak gagasan. Hal itu dapat melatih keterampilan sosial dan mempersiapkan siswa mengatasi tantanan kehidupan era global. Kecenderungan guru yang monoton dalam penggunaan metode menimbulkan masalah, yakni siswa dalam kehidupannya kurang cakap berorganisasi pada tingkat lokal maupun global.

Guru dapat melatih dan mengembangkan kemampuan berpikir kritis siswa melalui partisipasi aktif dalam pembelajaran melalui metode pembelajaran kooperatif. Siswa akhirnya harus memiliki kemampuan berpikir kritis untuk memahami realita kehidupan dan dapat memecahkan setiap permasalahan dalam kehidupannya dan merasakan manfaat dari pembelajaran sejarah.

Anderson dan Krathwohl (2010: 47) mengklasifikasikan hasil belajar ke dalam tiga ranah yaitu kognitif (kemampuan berpikir), afektif (kemampuan bersikap), dan psikomotor (kemampuan keterampilan). Ranah kognitif bertujuan melatih kemampuan intelektual siswa, ranah afektif terkait dengan sikap, emosi, penghargaan dan penghayatan terhadap nilai, norma dan sesuatu yang sedang dipelajari, sementara ranah psikomotorik memiliki kaitan dengan kemampuan melakukan kegiatan bersifat fisik dalam berbagai mata pelajaran.

Gagne dalam Sudjana (2010: 22) mengembangkan kemampuan hasil belajar menjadi lima macam antara lain:

1) Hasil belajar intelektual

2) Strategi kognitif yaitu mengatur cara belajar dan berpikir seseorang dalam arti seluas-luasnya termasuk kemampuan memecahkan masalah

3) Sikap dan nilai yang berhubungan dengan arah intensitas emosional yang dimiliki seseorang sebagaimana disimpulkan dari kecenderungan bertingkah laku terhadap 
orang dan kejadian

4) Informasi verbal, pengetahuan dalam arti informasi dan fakta

5) Keterampilan motorik yaitu kecakapan yang berfungsi untuk lingkungan hidup serta memprestasikan konsep dan lambang.

Winkel (2009: 104) menyatakan bahwa hasil belajar adalah perubahan yang mengakibatkan manusia berubah dalam sikap dan tingkah lakunya sehingga dapat menjadi indikator kualitas dan kuantitas bagi siswa. Sementara Lindgren dalam Suprijono (2009: 7) menyatakan bahwa hasil belajar meliputi kecakapan, informasi, pengertian dan sikap, dengan kata lain hasil belajar adalah perubahan perilaku secara keseluruhan. Menurut Briggs dalam Sudjana (2010: 2), hasil belajar adalah seluruh kecakapan dan segala hal yang diperoleh melalui proses pembelajaran yang dinyatakan dengan angka dan diukur dengan tes hasil belajar.

Hasil belajar tersebut dapat berfungsi sebagai refleksi terhadap proses pembelajaran yang dilaksanakan guru pada saat kegiatan pembelajaran, terutama yang berkaitan dengan metode pembelajaran. Hasil belajar pada akhirnya sangat dipengaruhi pemilihan dan penggunaan metode pembelajaran yang tepat dan sesuai dengan materi ajar yang akan disampaikan. Siswa dapat mencapai hasil belajar yang optimal apabila guru tepat dalam menggunakan metode pembelajaran.

Dick dan Carrey (2008: 186-196) menyatakan ada lima komponen metode pembelajaran yang perlu mendapat perhatian yaitu:

1) Memotivasi siswa

2) Memberikan informasi tentang materi yang akan diberikan dan tujuan pembelajaran yang akan dicapai sebelum pembelajaran dimulai.

3) Memperhatikan umpan balik.

4) Memberikan beberapa tes formatif sebagai kontrol pencapaian tujuan pembelajaran sesuai dengan materi yang telah diberikan
5) Tindak lanjut setelah proses pembelajaran berakhir.

Menurut Moore (2005: 266) metode pembelajaran kooperatif merupakan hasil dari pendekatan pembelajaran yang tidak hanya mengarahkan siswa dalam kelompok tetapi juga memfasilitasi siswa agar dapat bekerja sama satu sama lain dalam menyelesaikan tugas yang diberikan. Hal itu sesuai dengan pendapat Melvin (2011: 30) bahwa metode pembelajaran kooperatif merupakan suatu proses penciptaan lingkungan pembelajaran kelas yang memungkinkan siswa bekerja sama dalam kelompok kecil yang heterogen. Siswa diarahkan untuk bekerja sama dalam suatu kelompok kecil yang memiliki kemampuan berbeda-beda dengan tujuan agar saling bekerjasama dalam menyelesaikan masalah dan saling membantu dalam memahami materi pelajaran. Guru sebagai fasilitator dapat memberikan bantuan kepada siswa berupa arahan, petunjuk, peringatan, contoh, dan uraian permasalahan yang dapat memudahkan siswa untuk memahaminya.

Pemahaman tersebut sejalan dengan pendekatan konstruktivisme yang penekanannya pada lingkungan sosial dalam belajar. Menurut pandangan konstruktivisme, siswa membina pengetahuan baru berdasarkan pengetahuan yang dimiliki sebelumnya melalui pengalaman belajarnya.

Menurut Curran dalam Huda (2011: 113) metode pembelajaran model mencari pasangan adalah teknik di mana siswa digabung untuk mencari pasangan dari kartu yang mereka pegang. Siswa mencari pasangan sambil belajar mengenai suatu konsep atau topik dalam suasana yang menyenangkan. Teknik ini dapat digunakan dalam semua mata pelajaran dan untuk semua tingkatan usia siswa.

Lie (2007: 28) menyatakan pembelajaran kooperatif merupakan pembelajaran gotong royong yang memberikan kesempatan kepada siswa untuk bekerja sama dengan siswa lain dalam menyelesaikan tugas. Proses pembelajaran berlangsung setelah terbentuk 
kelompok siswa. Mereka bekerja secara terarah untuk mencapai tujuan yang sudah ditentukan. Siswa dapat belajar memahami suatu konsep atau materi dengan suasana yang menyenangkan melalui metode pembelajaran kooperatif model mencari pasangan.

Menurut Barry dan King (2004: 61) metode pembelajaran konvensional merupakan metode yang biasa digunakan guru dalam pembelajaran di kelas untuk menyampaikan informasi secara verbal. Salah satu bentuk metode konvensional yang biasa dilakukan adalah ceramah. Metode ini menekankan pembelajaran satu arah dari guru kepada siswa karena guru lebih aktif dalam menyampaikan materi pembelajaran. Menurut Gilstrap dan Martin dalam Azis (2012: 88) metode ceramah berasal dari kata Latin lego yang berarti membaca yang kemudian diartikan secara umum dengan mengajar sebagai akibat guru menyampaikan pembelajaran atau mendiktekan materi pembelajaran dengan bersumber pada buku.

Johnson (2006: 183) memaknai berpikir kritis sebagai proses terarah dan jelas dalam kegiatan mental seperti memecahkan masalah, mengambil keputusan, membujuk, menganalisis asumsi dan melakukan penelitian ilmiah. Berpikir kritis adalah kemampuan berpendapat dengan cara terorganisasi dan mengevaluasi secara sistematis bobot pendapat pribadi dari pendapat orang lain.

Pada saat berpikir, manusia pada hakekatnya sedang belajar menggunakan kemampuan berpikirnya secara intelektual. Saat berpikir terlintas beberapa alternatif solusi dan mempertimbangkan solusi yang dianggap tepat dalam menyelesaikan masalah. Selanjutnya, manusia akan memilih solusi yang dianggap paling baik dan tepat. Hal tersebut senada dengan pendapat Ennis dalam Fisher (2009: 4) bahwa berpikir kritis adalah berpikir beralasan dan reflektif yang bertujuan membuat keputusan yang masuk akal.

Santrok (2007: 359) mengemukakan cara-cara guru mengembangkan kemampuan berpikir kritis siswa dalam pembelajaran adalah:
1) Seorang guru tidak hanya menanyakan apa yang terjadi tetapi juga menanyakan bagaimana dan mengapa suatu peristiwa bisa terjadi sehingga siswa belajar menganalisis permasalahan dan mengasah ketajaman berpikirnya. Siswa belajar bertanya dan mengemukakan gagasannya.

2) Siswa dilatih mengkaji dugaan fakta untuk mengetahui apakah ada bukti yang mendukungnya sehingga siswa dapat belajar berargumentasi berdasarkan buktibukti yang dapat dipertanggungjawabkan kebenarannya. Siswa dilatih dalam mengidentifikasi setiap informasi yang diterimanya, membedakan fakta yang relevan dan yang tidak relevan dan menganalisis hubungan sebab akibat dari informasi yang diterimanya.

3) Melatih keberanian mengemukakan gagasan dalam berdebat secara rasional dan mengutamakan etika penggunaan bahasa yang santun.

4) Siswa belajar mengemukakan jawaban dari berbagai sudut pandang hingga menyadari alternatif jawaban dan penjelasan yang lebih baik.

5) Membandingkan berbagai jawaban untuk suatu pertanyaan dan menilai mana yang benar-benar jawaban terbaik.

6) Mengevaluasi berbagai pendapat yang dikemukakan siswa dan menyimpulkan pernyataan-pernyataan yang dianggap benar.

7) Melatih kemampuan siswa dalam bertanya di luar yang sudah diketahui untuk menciptakan ide baru atau informasi baru.

Menurut Rubber dalam Amri (2010: 64) berpikir kritis menuntut siswa menggunakan strategi kognitif tertentu yang tepat untuk menguji keandalan gagasan, pemecahan masalah, dan mengatasi masalah. Ide-ide dan pemecahan masalah dapat terwujud bila cara berpikir dikendalikan oleh kesadaran yang terarah, terencana, dan mengikuti alur logis sesuai fakta yang diketahui. Menurut 
Moon (2008: 22) berpikir kritis berarti memiliki kemampuan bertanya secara jelas dan beralasan, membuktikan sesuatu disertai bukti, berusaha memahami masalah dengan baik, menggunakan sumber yang terpercaya dan mampu mempertimbangkan berbagai informasi yang berbeda untuk diolah, dianalisis dan disimpulkan. Kemampuan berpikir kritis tersebut harus dibangun dengan melatih siswa dalam menentukan posisi dan setiap keputusannya benar-benar datang dari dirinya sendiri bukan atas dasar pengaruh orang lain. Keterampilan berpikir kritis dapat dikembangkan pada siswa melalui hasil latihan secara berkelanjutan. Siswa dapat dihadapkan pada suatu isu persoalan yang menuntut sikap kritis siswa untuk mempertanyakan dan meragukan suatu kebenaran melalui logika berpikir. Setiap siswa memiliki cara pandang sendiri dalam memahami dan menyelesaikan permasalahan. Cara pandang yang didasari oleh berbagai alasan yang masuk akal penting dilakukan dalam mengemukakan argumen. Ketika berargumen dengan menggunakan penalarannya, berarti siswa sedang melakukan tindakan berpikir kritis.

Berdasarkan pemaparan di atas, tujuan dari penelitian ini adalah untuk mengetahui:

1) Perbedaan hasil belajar sejarah siswa yang diberikan metode pembelajaran kooperatif model mencari pasangan dan metode pembelajaran konvensional

2) Pengaruh interaksi antara metode pembelajaran dan kemampuan berpikir kritis terhadap hasil belajar sejarah siswa

3) Perbedaan hasil belajar sejarah antara siswa yang diberikan metode pembelajaran kooperatif model mencari pasangan dengan kemampuan berpikir kritis tinggi dan siswa yang diberikan metode pembelajaran konvensional dengan kemampuan berpikir kritis tinggi

4) Perbedaan hasil belajar sejarah siswa yang diberikan metode pembelajaran kooperatif model mencari pasangan dengan kemampuan berpikir kritis rendah dan siswa yang diberikan metode pembelajaran konvensional dengan kemampuan berpikir kritis rendah

\section{Metodologi Penelitian}

Metode penelitian yang digunakan adalah metode penelitian kuantitatif dengan menggunakan jenis penelitian eksperimen dengan treatment by level $2 \times 2$. Variabel bebas dalam penelitian ini adalah metode pembelajaran kooperatif model mencari pasangan dan metode pembelajaran konvensional, variabel moderatornya adalah kemampuan berpikir kritis yang digunakan untuk meneliti ada tidaknya hubungan sebab akibat dengan cara memberi perlakuan terhadap kelompok eksperimen, sedangkan variabel terikatnya adalah hasil belajar sejarah.

Populasi dalam penelitian ini adalah siswa SMA Bunda Hati Kudus, populasi terjangkaunya adalah siswa kelas XI yang terdiri dari empat kelas dengan jumlah 96 siswa. Teknik pengambilan sampel menggunakan teknik random sampling yaitu sampel yang diambil secara acak tanpa memperhatikan strata yang ada dalam populasi tersebut. Kelas XI IPS sebagai sampel, kelas XI IPS 1 sebagai kelas eksperimen dan kelas XI IPS 2 sebagai kelas kontrol. Seluruh siswa dalam kedua kelas tersebut diukur kemampuan berpikir kritisnya melalui kuesioner dan hasilnya diurutkan dari skor tertinggi sampai skor terendah, kemudian diambil $27 \%$ kelompok atas yang dinyatakan sebagai kelompok yang memiliki kemampuan berpikir kritis tinggi dan $27 \%$ sebagai kelompok yang memiliki kemampuan berpikir kritis rendah.

Metode pembelajaran kooperatif model mencari pasangan akan diberikan kepada siswa kelas XI IPS 1, sedangkan kelas XI IPS 2 menggunakan metode pembelajaran konvensional. Perlakuan akan diberikan selama 8 kali pertemuan, bagi kelas yang menggunakan metode kooperatif model mencari pasangan akan diarahkan ke dalam kelompok 4-5 orang, sementara bagi kelas yang tidak mendapat perlakuan akan dibimbing oleh guru melalui metode pembelajaran konvensional dengan metode ceramah.

Instrumen yang digunakan untuk mengumpulkan data mengenai kemampuan berpikir kritis menggunakan kuesioner 
skala likert, sedangkan variabel terikatnya menggunakan tes hasil belajar. Validitas instrumen kemampuan berpikir kritis diuji dengan menggunakan rumus product moment dan reliabilitas instrumen diuji menggunakan rumus alpha cronbach. Validitas instrumen hasil belajar sejarah diuji menggunakan korelasi point biserial dan reliabilitas instrumen diuji dengan rumus KR-20.Untuk pengujian hipotesis menggunakan analisis varians dua jalur (ANAVA $2 \times 2$ ) dengan taraf signifikansi $5 \%$. Sebelum data diolah menggunakan analisis varians $2 \times 2$ dilakukan uji prasyarat yang meliputi uji normalitas dan homogenitas variansi. Uji normalitas dilakukan dengan menggunakan metode Lilliefors, sedangkan uji homogenitas variansi menggunakan uji Bartlet. Jika hasil pengujian menunjukkan adanya perbedaan dan interaksi, maka untuk mengetahui kelompok mana yang lebih tinggi hasil belajarnya, dilakukan pengujian dengan uji Tuckey.

\section{Hasil Penelitian dan Pembahasan}

Hipotesis pertama menyatakan bahwa terdapat perbedaan hasil belajar antara siswa yang diberikan metode pembelajaran kooperatif model mencari pasangan dandengan siswa yang diberikan metode pembelajaran konvensional.

Berdasarkan perhitungan ANAVA dua jalur diperoleh $F_{\text {hitung }}$ untuk metode pembelajaran (dalam kolom) sebesar 8,754, sedangkan Ftabel $=4,20$ pada taraf nyata $\mathrm{a}=0,05$. Karena nilai $\mathrm{F}_{\text {hitung }}>\mathrm{F}_{\text {tabel' }}$ maka hipotesis nol (Ho) ditolak dan $\mathrm{H}_{1}$ diterima dan menunjukkan bahwa terdapat perbedaan hasil belajar sejarah antara siswa yang diberikan metode pembelajaran model mencari pasangan dan konvensional.

Uji lanjut dengan Uji Tuckey menunjukkan bahwa nilai Qhitung $=4,18$ yang lebih besar dari Qtabel $(0,05 ; 16 ; 2)=3,00$. Dapat disimpulkan bahwa hasil belajar sejarah siswa untuk kelompok siswa yang diberikan metode pembelajaran model mencari pasangan lebih tinggi dari siswa yang diberikan metode pembelajaran konvensional. Rangkuman hasil Uji Tuckey dapat dilihat pada tabel berikut:

\section{Tabel 1}

Rangkuman Uji Tuckey Hasil Belajar Sejarah Antara Siswa Yang Diberikan Metode Pembelajaran Kooperatif Model Mencari Pasangan dan Metode Pembelajaran Konvensional

\begin{tabular}{|l|c|c|}
\hline $\begin{array}{c}\text { Kelompok yang } \\
\text { Dibandingkan }\end{array}$ & $\mathbf{Q}_{\text {hitung }}$ & $\mathbf{Q}_{\text {tabel }}$ \\
\cline { 3 - 3 } & $\boldsymbol{\alpha}=\mathbf{0 , 0 5}$ \\
\hline $\mathrm{A}_{1}$ dan $\mathrm{A}_{2}$ & 4,18 & 3,00 \\
\hline
\end{tabular}

Keterangan:

$\mathrm{A}_{1}$ : Metode pembelajaran kooperatif model mencari pasangan

$\mathrm{A}_{2}$ : Metode pembelajaran konvensional

Hipotesis kedua menyatakan bahwa terdapat pengaruh interaksi antara penggunaan metode pembelajaran dan kemampuan berpikir kritis terhadap hasil belajar sejarah siswa. Berdasarkan hasil perhitungan ANAVA dapat dilihat bahwa Fhitung untuk faktor interaksi yaitu 108,574 lebih besar daripada Ftabel yaitu 4,20 pada taraf nyata $\alpha=0,05$. Hal ini menunjukkan terdapat pengaruh interaksi antara penggunaan metode pembelajaran dan kemampuan berpikir kritis terhadap hasil belajar sejarah siswa, di mana $\mathrm{H}_{0}$ ditolak dan $\mathrm{H}_{1}$ diterima. Untuk melihat signifikansinya selanjutnya dilakukan Uji Tuckey antara kelompok $\mathrm{A}_{1} \mathrm{~B}_{1}$ dan $\mathrm{A}_{2} \mathrm{~B}_{2}$ yang disebut $\mathrm{Q}_{14}$ serta antara kelompok $A_{1} B_{2}$ dan $A_{2} B_{1}$ yang disebut Q23 sebagai berikut: Nilai rerata $A_{1} B_{1}=34,13$ dan nilai rerata $A_{2} B_{2}=28,13$ Nilai rerata $A_{1} B_{2}=$ 20,88 dan nilai rerata $A_{2} B_{1}=21,13$ Nilai RJKD $=$ 7,55

$\mathrm{Q}=\frac{\bar{X}_{L}-\bar{X}_{S}}{S_{\bar{x}}} ; S_{\bar{x}}=\sqrt{\frac{R J K D}{n}}$

Keterangan :

RJKD = rerata jumlah kuadrat dalam

$\mathrm{X}_{\mathrm{L}} \quad=$ rata-rata yang paling besar 
$\mathrm{X}_{\mathrm{S}} \quad=$ rata-rata yang paling kecil

$\mathrm{q} \quad=$ angka Tuckey yang diperoleh dari perhitungan

$\mathrm{n} \quad=$ banyaknya data tiap kelompok

$$
\begin{aligned}
& \mathrm{Q}_{2}=\frac{(34,13-28,13)}{\sqrt{\frac{7,55}{16}}}=4,18 \\
& \mathrm{Q}_{3}=\frac{(34,13-28,13)}{\sqrt{\frac{7,55}{16}}}=4,18
\end{aligned}
$$

Tabel 2

Rangkuman Uji Tuckey Pengaruh Interaksi antara Metode Pembelajaran dan Berpikir

Kritis

\begin{tabular}{|c|c|c|}
\hline $\begin{array}{c}\text { Kelompok yang } \\
\text { Dibandingkan }\end{array}$ & $\mathbf{Q}_{\text {hitung }}$ & $\mathbf{Q}_{\text {tabel }}$ \\
\cline { 3 - 3 } & $\boldsymbol{\alpha} \mathbf{0 , 0 5}$ \\
\hline $\mathrm{A}_{1} \mathrm{~B}_{1}$ dan $\mathrm{A}_{2} \mathrm{~B}_{2}$ & 8,73 & 3,00 \\
$\mathrm{~A}_{1} \mathrm{~B}_{2}$ dan $\mathrm{A}_{2} \mathrm{~B}_{1}$ & 0,36 & 3,00 \\
\hline
\end{tabular}

Hasil ini menunjukkan bahwa $\mathrm{Q}_{\text {hitung }}=$ 8,73 dan 0,36 salah satunya Iebih besar dari $\mathrm{Q}_{\text {tabel }}(0,05 ; 4 / 72)=3,00$ yang berarti bahwa terdapat pengaruh interaksi antara metode pembelajaran (kooperatif atau konvensional) dan kemampuan berpikir kritis (tinggi atau rendah) terhadap hasil belajar sejarah siswa.

Hipotesis ketiga menyatakan bahwa siswa yang mempunyai kemampuan berpikir kritis tinggi, terdapat perbedaan hasil belajar sejarah siswa antara yang diberikan metode pembelajaran kooperatif model mencari pasangan dan konvensional.

Nilai rerata hasil belajar sejarah siswa yang memiliki kemampuan berpikir kritis tinggi bila diberikan metode pembelajaran kooperatif $\left(A_{1} B_{1}\right)$ adalah 34,13 , sedangkan nilai rerata hasil belajar sejarah siswa yang memiliki kemampuan berpikir kritis tinggi bila diberikan metode pembelajaran konvensional $\left(A_{2} B_{1}\right)$ adalah 21,13. Kedua nilai rerata ini dibedakan dengan menggunakan Uji Tuckey yang dilambangkan dengan $Q_{12}$ sebagai berikut:

$$
\mathrm{Q}_{4}=\frac{(34,13-21,13)}{\sqrt{\frac{7,55}{8}}}=13,38
$$

Hasil ini menunjukkan bahwa $Q_{\text {hitung }}$ yaitu $13,38>Q_{\text {tabel }}$ yaitu 4,04 pada taraf nyata $\alpha=0,05$. Maka dapat disimpulkan bahwa Ho ditolak dan $\mathrm{H}_{1}$ diterima yang berarti bahwa siswa yang memiliki kemampuan berpikir kritis tinggi yang diberikan metode pembelajaran kooperatif model mencari pasangan lebih tinggi dari siswa yang diberikan metode pembelajaran konvensional. Rangkuman hasil Uji Tuckey dapat dilihat pada tabel berikut ini:

Tabel 3

Rangkuman Uji Tuckey Hasil Belajar Sejarah Siswa untuk kelompok dengan berpikir kritis tinggi yang diberikan metode pembelajaran kooperatif model mencari pasangan dan konvensional

\begin{tabular}{|l|c|c|}
\hline $\begin{array}{c}\text { Kelompok yang } \\
\text { Dibandingkan }\end{array}$ & $\mathbf{Q}_{\text {hitung }}$ & $\mathbf{Q}_{\text {tabel }}$ \\
\cline { 3 - 3 } & $\boldsymbol{\alpha}=\mathbf{0 , 0 5}$ \\
\hline $\mathrm{A}_{1} \mathrm{~B}_{1}$ dan $\mathrm{A}_{2} \mathrm{~B}_{1}$ & 13,38 & 4,04 \\
\hline
\end{tabular}

Keterangan:

$\mathrm{A}_{1} \mathrm{~B}_{1}$ : Hasil belajar sejarah siswa dengan berpikir kritis tinggi yang diberikan metode pembelajaran model mencari pasangan

$\mathrm{A}_{2} \mathrm{~B}_{1}$ : Hasil belajar dengan berpikir kritis tinggi yang diberikan metode pembelajaran konvensional

Hipotesis keempat menyatakan bahwa siswa yang memiliki kemampuan berpikir kritis rendah, terdapat perbedaan hasil belajar sejarah antara siswa yang diberikan metode pembelajaran model mencari pasangan dan konvensional.

Nilai rerata hasil belajar sejarah siswa yang memiliki kemampuan berpikir kritis rendah bila diberikan metode pembelajaran kooperatif model mencari pasangan $\left(\mathrm{A}_{1} \mathrm{~B}_{2}\right)$ adalah 20,88, sedangkan nilai rerata 
hasil belajar sejarah siswa yang memiliki kemampuan berpikir kritis rendah bila diberikan metode pembelajaran konvensional $\left(\mathrm{A}_{2} \mathrm{~B}_{2}\right)$ adalah 28,13 . Kedua nilai rerata ini dibandingkan dengan menggunakan Uji Tuckey dan diperoleh nilai $Q_{34}$ seperti berikut:

$$
\mathrm{Q}_{5}=\frac{(20,88-28,13)}{\sqrt{\frac{7,55}{8}}}=7,46
$$

Hasil ini menunjukkan bahwa nilai $\mathrm{Q}_{\text {hitung }}=7,46>$ nilai $\mathrm{Q}_{\text {tabel }}=4,04$ untuk taraf nyata $\alpha=0,05$. Maka dapat disimpulkan bahwa Ho ditolak dan $\mathrm{H}_{1}$ diterima yang berarti bahwa siswa dengan kemampuan berpikir kritis rendah yang diberikan metode pembelajaran kooperatif model mencari pasangan lebih rendah dari siswa yang diberikan metode pembelajaran konvensional. Hal ini menunjukkan bahwa siswa yang memiliki kemampuan berpikir kritis rendah lebih cocok diberikan pembelajaran dengan menggunakan metode pembelajaran konvensional. Rangkuman hasil Uji Tuckey untuk permasalahan tersebut dapat dilihat pada tabel di bawah ini:

\section{Tabel 4}

Rangkuman Uji Tuckey Hasil Belajar

Sejarah Siswa untuk kelompok berpikir kritis rendah yang diberikan metode pembelajaran kooperatif model mencari pasangan dan konvensional

\begin{tabular}{|l|c|c|}
\hline \multirow{2}{*}{$\begin{array}{c}\text { Kelompok yang } \\
\text { Dibandingkan }\end{array}$} & $\mathrm{Q}_{\text {hitung }}$ & $\mathrm{Q}_{\text {tabel }}$ \\
\cline { 3 - 3 } & & $\alpha=\mathbf{0 , 0 5}$ \\
\hline $\mathrm{A}_{1} \mathrm{~B}_{1}$ dan $\mathrm{A}_{2} \mathrm{~B}_{1}$ & 7,46 & 4,04 \\
\hline
\end{tabular}

Keterangan:

$A_{1} B_{2}$ : Hasil belajar sejarah siswa dengan berpikir kritis rendah yang diberikan metode pembelajaran kooperatif model mencari pasangan
$\mathrm{A}_{2} \mathrm{~B}_{2}$ : Hasil belajar sejarah siswa dengan berpikir kritis rendah yang diberikan metode pembelajaran konvensional

Adapun rangkuman hasil Uji Tuckey dapat dilihat padaTabel berikut ini:

Tabel 5

Rangkuman Hasil UjiTuckey

\begin{tabular}{|c|c|c|c|}
\hline \multirow{2}{*}{$\begin{array}{c}\text { Kelompok } \\
\text { yang } \\
\text { Dibandingkan }\end{array}$} & \multirow{2}{*}{$\mathbf{Q}_{\text {hitung }}$} & $Q_{\text {tabel }}$ & \multirow{2}{*}{$\begin{array}{c}\text { Kesim- } \\
\text { pulan }\end{array}$} \\
\hline & & $\alpha=0,05$ & \\
\hline $\mathrm{Q}_{\mathrm{k}}: \mathrm{A}_{1}$ dan $\mathrm{A}_{2}$ & 4,18 & 3,00 & Tolak $\mathrm{H}_{\mathrm{o}}$ \\
\hline (Interaksi) & & & \\
\hline $\mathrm{Q} 14: \mathrm{A}_{1} \mathrm{~B}_{1}$ dan $\mathrm{A}_{2} \mathrm{~B}_{2}$ & 8,73 & 3,00 & Tolak $\mathrm{H}_{\mathrm{o}}$ \\
\hline Q23: $A_{1} B_{2}$ dan $A_{2} B_{1}$ & 0,36 & & Terima $\mathrm{H}_{\mathrm{o}}$ \\
\hline $\mathrm{Q}_{12}: \mathrm{A}_{1} \mathrm{~B}_{1}$ dan $\mathrm{A}_{2} \mathrm{~B}_{1}$ & 13,38 & 4,04 & Tolak $\mathrm{H}_{\mathrm{o}}$ \\
\hline $\mathrm{Q} 34: \mathrm{A}_{1} \mathrm{~B}_{2} \operatorname{dan} \mathrm{A}_{2} \mathrm{~B}_{2}$ & 7,46 & 4,04 & Tolak $\mathrm{H}_{\mathrm{o}}$ \\
\hline
\end{tabular}

Melalui metode pembelajaran kooperatif model mencari pasangan, siswa termotivasi semangat belajarnya dengan proses pembelajaran yang menyenangkan. Siswa dibagi ke dalam kelompok kecil secara berpasangan dan masing-masing memegang kartu yang berisi pertanyaan dan jawaban. Di dalam proses pembelajaran tersebut siswa ditantang wawasan dan kemampuan berpikirnya mengenai materi sejarah ketika siswa harus mampu mencocokan pertanyaan dan jawaban yang benar. Metode pembelajaran ini dapat membangkitkan perhatian dan minat siswa untuk ikut terlibat sesuai dengan peranannya masing-masing, baik sebagai pemegang kartu pertanyaan, kartu jawaban dan tim penilai. Setelah siswa dirasakan yakin dengan pasangannya, guru memfasilitasi siswa ke dalam kelompok untuk mengkonfirmasi dan mengklarifikasi. Siswa juga diarahkan untuk memperdalam materi tersebut dalam kelompok, bertukar pendapat dan saling bekerjasama dalam memahami 
dan memecahkan permasalahan. Siswa pada akhirnya akan lebih mudah dalam menguasai materi tertentu dalam kerja sama kelompok dan pembelajaran menjadi lebih bermakna, sehingga dapat meningkatkan hasil belajar sejarah siswa.

Penggunaan metode pembelajaran kooperatif model mencari pasangan dan dengan metode pembelajaran konvensional dengan kemampuan berpikir kritis siswa berpengaruh terhadap hasil belajar sejarah siswa. Penggunaan metode pembelajaran dapat disesuaikan dengan kemampuan berpikir kritis siswa sehingga dapat meningkatkan hasil belajar sejarah siswa.

Penggunaan metode pembelajaran kooperatif model mencari pasangan untuk siswa yang memiliki kemampuan berpikir kritis tinggi memiliki pengaruh yang lebih tinggi terhadap hasil belajar sejarah siswa. Siswa yang memiliki kemampuan berpikir kritis tinggi dapat menggunakan pemikirannya untuk memahami dan menganalisis setiap permasalahan dan mampu memahami materi ajar dengan lebih baik. Siswa dapat menguasai materi ajar melalui proses kerjasama dalam kelompok kecil, melatih kemampuan berpikirnya dalam menyelesaikan masalah dan semakin memperkaya pengalaman belajarnya, sehingga metode pembelajaran kooperatif model mencari pasangan lebih cocok diberikan pada siswa yang memiliki kemampuan berpikir kritis tinggi.

Penggunaan metode pembelajaran konvensional memiliki efek yang lebih tinggi terhadap peningkatan hasil belajar sejarah siswa. Siswa yang memiliki kemampuan berpikir kritis rendah memperoleh hasil belajar sejarah yang lebih tinggi jika diberikan metode pembelajaran konvensional dari siswa yang diberikan metode pembelajaran kooperatif model mencari pasangan.

Siswa yang memiliki kemampuan berpikir kritis rendah apabila diberikan metode pembelajaran kooperatif model mencari pasangan, hasil belajarnya lebih rendah dari siswa yang diberikan metode pembelajaran konvensional. Hal itu dikarenakan siswa lebih bersikap pasif dalam menerima materi ajar dan lebih tergantung pada apa yang disampaikan guru. Ketika guru memfasilitasi siswa dalam kelompok kecil, proses pembelajarannya justru tidak berjalan dengan semestinya karena siswa tidak memiliki kemampuan berpikir kritis tinggi dalam memahami permasalahan yang diajukan guru melalui berbagai pertanyaan. Siswa akan kesulitan dalam menguasai materi ajar karena mereka dituntut untuk saling bekerjasama dalam kelompok yang diharapkan terjadi interaksi untuk saling bertukar pendapat. Pembelajaran kooperatif model mencari pasangan ini membutuhkan analisis yang tinggi dan keaktifan dari siswa sendiri untuk mencari dan memecahkan masalah melalui kerjasama kelompok, sehingga metode pembelajaran kooperatif model mencari pasangan tidak cocok diberikan kepada siswa yang memiliki kemampuan berpikir kritis rendah.

Sebaliknya, siswa yang memiliki kemampuan berpikir kritis rendah apabila diberikan metode pembelajaran konvensional hasil belajarnya lebih tinggi. Siswa yang memiliki kemampuan berpikir kritis rendah tentunya sudah terbiasa dengan metode pembelajaran konvensional melalui bimbingan materi secara langsung dari guru. Melalui metode pembelajaran konvensional, siswa yang memiliki kemampuan berpikir kritis rendah akan dimotivasi dengan penggunaan media, ceramah bervariasi dan bercerita. Hal ini menyebabkan siswa lebih mudah memahami konsep-konsep dan materi yang cakupannya luas. Pemahaman tersebut berpengaruh pada hasil belajar sejarah siswa yang lebih tinggi, sehingga dapat disimpulkan bahwa metode pembelajaran konvensional lebih cocok diberikan kepada siswa yang memiliki kemampuan berpikir kritis rendah.

\section{Kesimpulan dan Saran}

Berdasarkan hasil pengujian hipotesis penelitian ini menyimpukan:

Pertama; Hasil belajar sejarah siswa yang diberikan metode pembelajaran kooperatif model mencari pasangan lebih tinggi dari 
siswa yang diberikan metode pembelajaran konvensional.

Kedua; Terdapat pengaruh interaksi antara metode pembelajaran dan kemampuan berpikir kritis terhadap hasil belajar sejarah siswa.

Ketiga; hasil belajar sejarah siswa yang diberikan metode pembelajaran kooperatif model mencari pasangan dengan kemampuan berpikir kritis tinggi lebih tinggi dari siswa yang diberikan metode pembelajaran konvensional dengan kemampuan berpikir kritis tinggi.

Keempat; hasil belajar sejarah siswa yang diberikan metode pembelajaran kooperatif model mencari pasangan dengan kemampuan berpikir kritis rendah lebih rendah dari siswa yang diberikan metode pembelajaran konvensional dengan kemampuan berpikir kritis rendah.

Implikasi dari empat kesimpulan di atas adalah:

1. Penggunaan metode pembelajaran kooperatif model mencari pasangan dalam pembelajaran sejarah dapat memberikan hasil yang lebih baik dari metode pembelajaran konvensional

2. Metode pembelajaran dan kemampuan berpikir kritis dapat mempengaruhi hasil belajar sejarah.

3. Hasil belajar sejarah siswa yang diberikan metode pembelajaran kooperatif model mencari pasangan dengan kemampuan berpikir kritis tinggi lebih tinggi dari siswa yang diberikan metode pembelajaran konvensional. Metode pembelajaran kooperatif model mencari pasangan lebih cocok diberikan pada siswa yang memiliki kemampuan berpikir kritis tinggi.

4. Hasil belajar sejarah siswa yang diberikan metode pembelajaran kooperatif model mencari pasangan dengan kemampuan berpikir kritis rendah lebih rendah dari siswa yang diberikan metode pembelajaran konvensional. Metode pembelajaran konvensional lebih tepat diberikan pada siswa yang memiliki kemampuan berpikir kritis rendah, maka untuk meningkatkan hasil belajar sejarah siswa yang memiliki kemampuan berpikir kritis rendah, dapat diberikan metode pembelajaran konvensional.

Berdasarkan kesimpulan dan implikasi di atas, ada beberapa saran yang dapat dikemukakan:

1. Guru sejarah dapat menggunakan metode pembelajaran model mencari pasangan untuk meningkatkan hasil belajar sejarah siswa.

2. Guru memperhatikan kemampuan berpikir kritis yang dimiliki siswa sehingga dapat menyesuaikan metode pembelajaran yang akan digunakan. Guru dapat mengetahui tingkat kemampuan berpikir kritis siswa dengan memberikan tes kemampuan berpikir sebelum pembelajaran dimulai. Jika telah diketahui tingkat kemampuan berpikir kritis siswa, guru dapat menyesuaikan metode pembelajaran yang akan digunakan, sehingga dapat meningkatkan hasil belajar sejarah siswa.

3. Guru dapat menggunakan metode pembelajaran kooperatif model mencari pasangan bagi siswa yang memiliki kemampuan berpikir kritis tinggi, sehingga dapat meningkatkan hasil belajar sejarah siswa.

4. Guru dapat menggunakan metode pembelajaran konvensional bagi siswa yang memiliki kemampuan berpikir kritis rendah, sehingga dapat meningkatkan hasil belajar sejarah siswa. 


\section{Daftar Pustaka}

Anderson, Lorin W. Dan Krathwohl, Davit R. 2010. Pembelajaran, Pengajaran, dan Asesmen terjemahan Agung Prihantoro. Yogyakarta: Pustaka Pelajar.

Barry, Kevin and Len King. 2004. Beginning Teaching, A development Text for Effective Teaching. NewYork: Social Science Press.

Dick W and L. Carey. 2008. The Systematic Designs of Instructional Tallahase. Florida: Harpers Collins Publisher.

Fisher, Alec. 2009. Berpikir Kritis. Terjemahan Benyamin Hadinata. Jakarta: Erlangga.

Hapsari, Ratna. “Tujuan Pendidikan Sejarah," Jakarta: Jurnal Pendidikan Sejarah-AGSI, 2011.

Huda, Miftahul. 2011. Cooperative Learning: Metode, Teknik, Struktur dan Model Penerapan. Yogyakarta: Pustaka Pelajar.

Johnson, Elaine B. 2006. Contextual Teaching and Learning. Menjadikan kegiatan belajar-mengajar mengasyikkan dan bermakna. Terjemahan oleh Ibnu Setiawan, Bandung: Mizan Learning Center.
Lie, Anita. 2007. Cooperative Learning. Jakarta: Grasindo, 2007.

Moon, Jenifer. 2008. Critical Thinking An ekploration of theory and practice. New York: Routledge.

Moore, Kennet D. 2005. Effective Instructional Strategies From Theory to Practise. London: Sage Publications.

Santrok, John W. 2007. Psikologi pendidikan edisi ke 2. Jakarta: Kencana Prenada Media Grup.

Sudjana, Nana. 2010. Penilaian Hasil Proses Belajar Mengajar. Bandung: PT. Ramaja Rosdakarya.

Suprijono, Agus. 2009. Cooperative Learning: Teori dan Aplikasi Paikem. Pustaka Pelajar: Yogyakarta.

Silberman, Melvin L. 2011. Cara Belajar Siswa Aktif. Terjemahan Raisul Muttaqien Bandung: Nusa Media.

Winkel, W.S. 2009. Psikologi Pengajaran. Yogyakarta: Media Abadi. 